\title{
Subsystemic Unipolarities? Power Distribution and State Behaviour in South America and Southern Africa
}

\author{
Luis Leandro Schenoni
}

\begin{abstract}
This article explores the possibility of conceiving South America and Southern Africa as subsystemic unipolarities under Brazilian and South African primacy, respectively. It argues that this concept, when applied to these regions, sheds light not only on the long-term strategies behind the Brazilian and South African foreign policies towards their neighbourhood, but also on the behaviour of secondary regional powers and small states. This hypothesis questions the maxim that considerations related to polarity affect great powers only. After examining the Brazilian and South African cases, the author undertakes a comparative analysis of 17 countries in these regions, showing that the behaviour of politically stable countries in these regions is as predicted by theories of unipolarity.
\end{abstract}

\section{Introduction}

$\mathrm{n}$ spite of the recent heightened interest in the regions of South America and Southern Africa ${ }^{1}$ few scholars have tried to apply a structural framework ${ }^{2}$ to understand them. ${ }^{3}$ Kenneth Waltz's assertion: 'A general theory of international politics is necessarily based on the great powers', was often interpreted by IR scholars as limiting the scope of structuralism to great power politics alone. But Waltz also meant that: 'The theory, once written, also applies to lesser states that interact insofar as their interaction is insulated from the intervention of the great powers of a system. ${ }^{4}$ In this article I intend to bring the structural framework back into regional politics in order to explore two regions that have similar sub-systemic power distributions. In doing so, I will depart from the recent debates on roles, ${ }^{5}$ leadership ${ }^{6}$ and status ${ }^{7}$ to highlight that the distribution of raw material capabilities can well explain certain regional phenomena, when mechanisms are properly understood.

Countries in the southernmost regions of the American and African continents display an outstandingly similar set of foreign policy strategies and international regimes. ${ }^{8}$ While these two regions are different in almost every relevant aspectregime type, levels of intra-regional trade, state capacity, etc.- they are similar in that only one country had roughly half of the region's material capabilities during the last three decades. Therefore, in accordance with John Stuart Mill's method of similarity, regional unipolarity should be considered as a potential explanation for their many parallelisms.

The adjective 'unipolar' describes a system where a single country excels in indicators of power such as population, resource endowment, economic capacity, military might, etc., while yet not necessarily conforming to a hegemony. ${ }^{9}$ Unipoles

Luis Leandro Schenoni is pursuing a $\mathrm{PhD}$ in Political Science at the University of Notre Dame, Notre Dame, IN. 
are expected to lead by actively participating in binding regional institutions; building ad hoc regional 'coalitions of the willing' to deal with major security or economic challenges; struggling for legitimacy without applying much coercion; and respecting the sovereignty of second-tier states, who are considered crucial partners, but are difficult to court. An important literature has already demonstrated that Brazil ${ }^{10}$ and South Africa ${ }^{11}$ behave in this way, yet very few scholars have considered power distribution as a cause of such behaviour.

The logics of unipolarity also seem to explain the behaviour of secondary and tertiary regional powers in these regions. In unipolar contexts, second-tier states - like Angola, Mozambique and Zimbabwe in Southern Africa; or Argentina, Chile, Colombia and Venezuela in South America - are expected to enact softbalancing, binding, delegitimizing, hedging or similar 'contestational' strategies against their unipole. ${ }^{12}$ Although these tactics have been intermittent, I will show that this is precisely what these countries tend to do when their domestic politics is stable. ${ }^{13}$ Finally, small states in unipolar regions-like Botswana, Lesotho, Madagascar, Namibia and Swaziland in Southern Africa; or Bolivia, Ecuador, Paraguay, Peru and Uruguay in South America - bandwagon the regional unipole, unless internal instability forces them to focus on the domestic realm and behave otherwise.

This article proceeds as follows. In the section 'South America and Southern Africa as unipolar subsystems', I analyse South America and Southern Africa in terms of power distribution to show that both regions were in fact unipolar during most of the last three decades. In the section 'Brazil and South Africa: behaving like unipoles', I build on existing case studies to show how Brazil and South Africa behaved as unipoles. Finally, in the section 'Secondary regional powers under unipolarity', I focus on 7 second-tier regional powers and 10 small states in order to analyse their strategies. I find that countries in these regions behaved as expected under unipolarity, unless they suffered from chronic domestic instability.

\section{South America and Southern Africa as unipolar subsystems}

Unipolarity refers to a particular distribution of power between hegemony and bi- or multi-polarity. Unipolarity is different from hegemony in that it does not entail a relation of domination, where the leading state is functionally different from its neighbours. ${ }^{14}$ However, unipoles are in a situation of relative primacy that is different from that of unbalanced bi or multipolar orders. As a convention, some scholars use the Composite Index of National Capabilities (CINC) to differentiate bipolar from unipolar settings. ${ }^{15}$ According to this convention, if the power of a leading state is more than three times that of the second biggest state, then the system is said to be unipolar.

Figure 1 shows the difference in power between South Africa-left - and Brazilright - compared with their biggest neighbours. The dashed line establishes the year in which Southern Africa became bipolar-2003, by these parameters - and the moment when the Argentine-Brazilian bipolarity gave way to Brazilian-led unipolarity in South America - roughly 1985. It could be argued that it took Brazil a little longer to behave like a unipole and that Angola has yet to fully comprehend its new relative power position in its region. Nevertheless, the CINC provides a robust structural snapshot of how power relations evolved in these two regions. Figure 2 uses data on military expenditures, this time from 1988 to 2014 , to show how the 


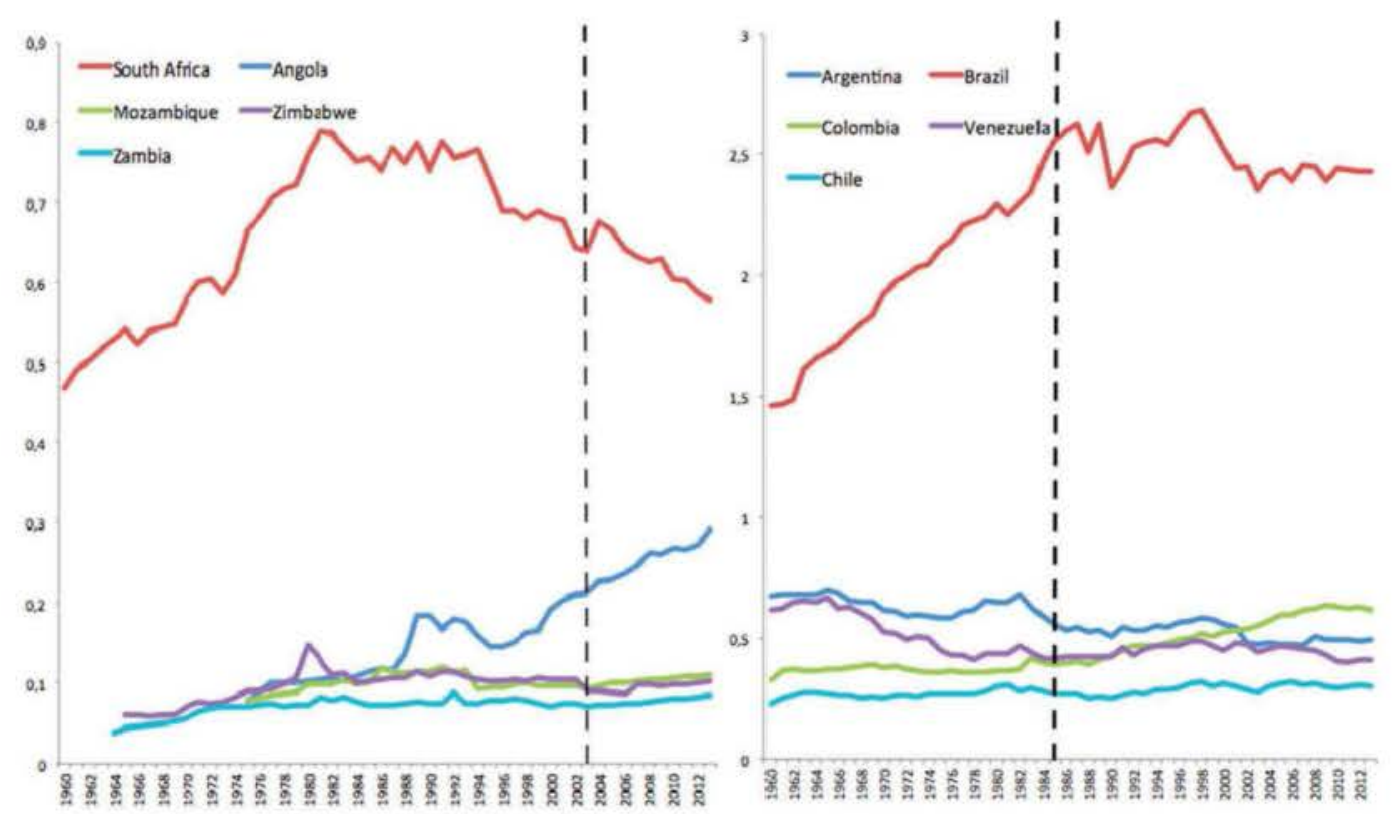

Figure 1. National capabilities of Southern African and South American five major countries from 1960 to 2013.

Notes: Values in y represent the country's share of world's national capabilities.

Source: CINC ${ }^{16}$. Victor Mijares updated the database for the years 2008-2013.
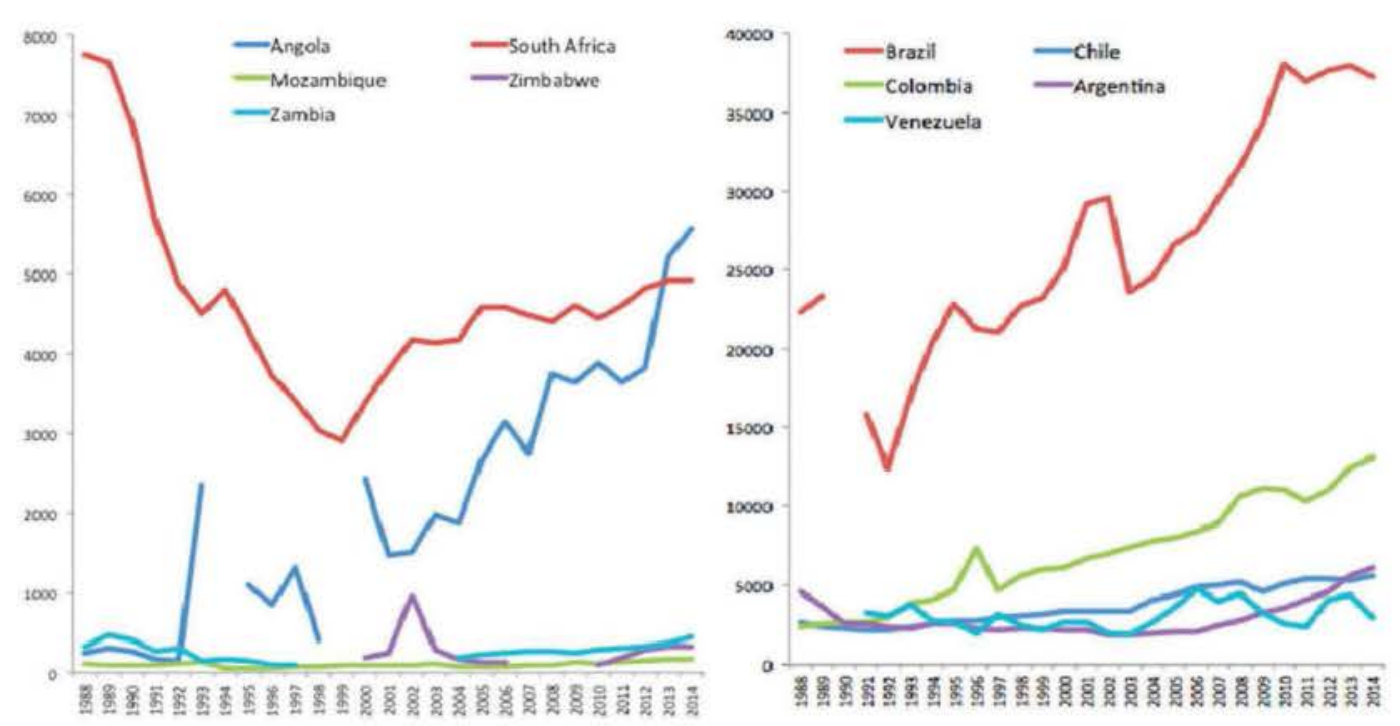

Figure 2. Military expenditures in Southern African and South American five major countries from 1988 to 2014.

Notes: Figures are in US\$ millions at constant 2011 prices and exchange rates. Missing data from Brazil and Angola were positive outliers excluded for the purpose of scaling and better demonstrating long-term tendencies.

Source: SIPRI Military Expenditures Database ${ }^{17}$.

Brazilian and South African primacy was also reflected in the military realm, during our period of interest.

Several other factors could be included in this assessment of regional power distribution. For instance, the picture just presented is agnostic to the great differences 
in terms of human resources, productivity and capital that still exist between Angola and South Africa. However, it is not my concern to establish a definitive measure of regional unipolarity. Instead, I try to show that these and many other potential variables are consistent with the idea that South America and Southern Africa have revealed important power disparities between first regional powers and secondary ones, for the most part of the latest three decades. These disparities are considerable, evidencing that the subsystems were not bi or multipolar. However, disparities were not big enough to allow for the rise of a regional hegemon - as South Africa was before $1980^{18}$ when it intervened systematically in its periphery. In other words, during the last three decades, both Brazil and South Africa have been in a position to lead their regional partners, but not in a position to coerce them. But the question remains: Did they behave as unipoles are expected to?

\section{Brazil and South Africa: behaving like unipoles}

According to a broad literature studying American primacy after the Cold War, unipoles have specific incentives to develop concrete foreign policies. In particular, unipoles are expected to lead by actively participating in binding regional institutions, building ad hoc regional 'coalitions of the willing' to deal with major security or economic challenges, struggling for legitimacy without applying great deals of coercion and respecting the sovereignty of second-tier states, which are considered crucial partners. ${ }^{19}$ Interestingly, Brazil and South Africa have behaved precisely in this way since the mid-1980s.

First, both regional unipoles have thought to integrate other countries and bind themselves to regional institutions. The unipolar Brazil '... like South Africa, thought to create regional alliances and a regional market, with mixed success, again like South Africa'. ${ }^{20}$ In the case of Brazil, these institutions were initially the Southern Common Market (MERCOSUR) and later on the Union of South American Nations (UNASUR), which consolidated the Brazilian idea of a united South America in 2004. Brazil has been trying to extend UNASUR's competences to several issue areas ever since, even competing with the Organization of American States (OAS). ${ }^{21}$ It would be a mistake, however, to think that MERCOSUR and UNASUR served Brazilian interests only. These institutions are better understood as the product of an extensive bargaining with second-tier powers, since they also bind Brazil considerably. ${ }^{22}$

The same could be said of the Southern African Development Community (SADC). It is true that 'Pretoria's foreign policy is an example of exercising power by participating effectively in regional and international institutions ${ }^{23}$ but South Africa joined only as the eleventh member of SADC in 1994, right after the dissolution of the Southern African Development Coordination Conference (SADCC) - an organization specially designed to balance its power in the region. The vision of the SADC founding fathers was to 'prepare unified negotiating positions on trade and other economic issues, craft a treaty based on progressive principles and entrench the concept of "balance, equity and mutual benefit" as the maxim for regional coordination'. ${ }^{24}$ Several features of the agreement serve to entangle Pretoria and could potentially undermine its primacy in the long term. ${ }^{25}$ In other words, South Africa chose to bind itself, ${ }^{26}$ as a strategy to gain legitimacy in the region and to be able to lead in a context where it was no longer a hegemon. 
Second, both countries have tried to court second-tier regional powers, minimizing the potential for bilateral conflict and by respecting their sovereignty at all costs. This has been the case even in contexts of widespread human rights violations as the Venezuelan and the Zimbabwean crises show. Why have Brasilia and Pretoria risked being seen as accomplices and protectors of cruel regimes by the international community? The response seems twofold. On the one side, secondary regional powers have enough power to retaliate - by means of regional interdependence or by building alliances with other second-tier powers against the unipole. On the other side, both Brazil and South Africa benefited to a great extent from the diminishing power of relatively big neighbours like Venezuela and Zimbabwe and, from a structural perspective, benefited greatly from their exsanguination. It is not surprising then that since becoming unipolar, South Africa also avoided any kind of intervention in Angola - at war until 2002 - or during the brief resumption of the civil war in Mozambique in 2013. The non-response of Brasilia to the 2001 Argentine crisis and the caution exercised during the Colombo-Venezuelan crisis in 2008 also contrast with the leadership role that it presumably seeks. However, the condescension vis-àvis second-tier states has a clear rationale, if we picture Brazil and South Africa as self-interested unipoles.

Third, regional unipoles in South America and Southern Africa have applied a completely different rule to small states. Since small states pose little peril to them, unipoles seem far more likely to intervene. Pretoria has actively interfered in the domestic politics of countries such as Lesotho (1994 and 1998), Swaziland (1994 and 2012) and Madagascar (2009). However, these interventions were never unilateral and were always intended as being part of the legitimizing brand of regional organizations. Even the South African invasion of Lesotho after the 1998 looting of Maseruan episode of political instability that threatened South African assets, water supplies and led the government of Lesotho to seek foreign support-was undertaken through a 'coalition of the willing' - joined by Botswana - and under SADC's mandate. Unlike a hegemon - and much like a regional unipole - South Africa's military intervention in this small state was preceded by the quest for legitimate leadership and burden-sharing with other actors in the system. In other cases like Madagascar (2009), South Africa did not intervene militarily but played a leading role in stabilizing Antananarivo through a SADC coalition. The way Pretoria intervened in this case has impressive resemblances with the Brazilian-led initiatives in Ecuador (2005 and 2010), Bolivia (2008), Honduras (2009) and Paraguay (2012) - all small states in South America - when these countries were experiencing episodes of political instability due to presidential crises. ${ }^{27}$ In all of these cases Itamaraty used the UNASUR to frame Brazilian initiatives as regionally coordinated responses.

Fourth, both Brazil and South Africa used their regions as a trampoline for their global ambitions. Analysts tend to agree that neither one of these emerging powers could have achieved the global status of China, India and Russia - true heavyweights in the economic and military realms - if it were not for the varnish of regional leadership. ${ }^{28}$ Most of the time, this strategy has required regional leaders on both sides of the South Atlantic to deal with contradictory demands from the global and the regional realms, to try to achieve a sustainable balance.

Fifth, as is also the case in the global realm, unipolarity has resulted in relatively peaceful and stable regional interstate relations. Only two militarized interstate disputes between Angola and Zambia (1998), and Zimbabwe and Botswana (2008), reached high levels of tension, and it was only during the Lesotho crisis (1998) that 
South Africa deployed its troops in another country. South America had been a peaceful region for a long time before Brazil acquired unipolar primacy in the mid$1980 \mathrm{~s}^{29}$ but even then the subsystem has been notably more stable than in the late 1970 s and early 1980s, when severe tensions between Argentina and Brazil, and Argentina and Chile, preceded the Malvinas/Falklands War (1982). Since Brazil became a unipole, only one proxy-war-between Ecuador and Peru in 1995-has taken place, which was settled, not surprisingly, in Brasilia. Besides the Cenepa War, only the Andean Crisis of 2008 created significant levels of tension in South America.

Summarizing, both Brazil and South Africa have shown stunning similarities in the way they have dealt with major and minor partners in their regions, and they have done so in ways that are consistent with theories of unipolarity.

\section{Secondary regional powers under unipolarity}

So far I have made the case for describing South America and Southern Africa as unipolar subsystems, but I have only referred to the capabilities (section 'South America and Southern Africa as unipolar subsystems') and behaviour of unipoles (section 'Brazil and South Africa: behaving like unipoles') to back this claim. However, if capability distribution matters at the regional level, other units in the subsystem should also behave as expected under unipolarity. To test this claim, I need to define the incentives that second-tier states and small states have in unipolar regions.

Some scholars have supported a straightforward logic to solve this riddle. ${ }^{30}$ Referring to the expected reactions to US primacy under unipolarity, they have observed that second-tier states - in this case, countries like China, India or Russia - have incentives to contest American leadership but secondary regional powerssay, Japan, Pakistan or Ukraine-would bandwagon the US in order to protect themselves from the rising power of their bigger neighbours, to somehow ensure an equilibrium in the unipolar structure. When applied to our regions, this logic suggests a specific pattern of alliances. On the one hand, secondary regional powers in South America-Argentina, Chile, Colombia and Venezuela; and Southern Africa-Angola, Mozambique and Zimbabwe-were expected to contest the Brazilian and South African primacy. ${ }^{31}$ On the other hand, small states historically at loggerheads with secondary regional powers and significantly less empowered-Bolivia, Ecuador, Paraguay and Uruguay, as well as Botswana, Lesotho, Madagascar, Malawi, Namibia and Swaziland-should have bandwagoned the unipoles in their respective regions.

Table 1 contrasts these theoretical expectations with the actual behaviour of second-tier and small states since the start of the new millennium. Secondary regional powers are expected to follow a hedging strategy, which I define as entailing (a) relatively low exports to the unipole, (b) relatively low imports from the unipole, (c) not entering into a free-trade agreement with the unipole and (d) maintaining relatively high military expenditures. I will consider any state that follows the opposite strategy to be 'bandwagoning' the regional unipole - which is the expected behaviour for small states.

The data displayed in Table 1 shows that only a handful of countries have behaved in accordance with structural theories - see the cases in grey. Among secondary regional powers, only Angola, Chile and Colombia have applied hedging strategies. Among small states, only Uruguay and Swaziland have consistently bandwagoned the 
Table 1. Expectations and actual behaviour toward unipoles (2000 2010).

\begin{tabular}{|c|c|c|c|c|c|c|c|c|c|}
\hline \multirow{2}{*}{$\frac{\text { South America }}{\text { Expectations }}$} & ARG & $\mathrm{CHI}$ & COL & VEN & PER & BOL & $\mathrm{ECU}$ & PAR & \multirow[b]{2}{*}{ URU } \\
\hline & \multicolumn{4}{|c|}{ Expected to Hedge $(\mathrm{H})$} & \multicolumn{4}{|c|}{ Expected to Bandwagon (B) } & \\
\hline Exports & $\mathrm{HIGH}$ & LOW & LOW & MED & LOW & $\mathrm{HIGH}$ & LOW & MED & $\mathrm{HIGH}$ \\
\hline Imports & $\mathrm{HIGH}$ & LOW & LOW & MED & LOW & MED & LOW & $\mathrm{HIGH}$ & HIGH \\
\hline MERCOSUR & YES & NO & NO & YES & $\mathrm{NO}$ & YES & $\mathrm{NO}$ & YES & YES \\
\hline Military & LOW & HIGH & $\mathrm{HIGH}$ & LOW & LOW & LOW & HIGH & Low & LOW \\
\hline Behaviour & $\mathrm{B}$ & $\mathrm{H}$ & $\mathrm{H}$ & B & $?$ & $?$ & $\mathrm{H}$ & $?$ & B \\
\hline Southern Africa & ANG & MOZ & ZIM & & BOT & LES & MAD & NAM & SWA \\
\hline Expectations & Expec & $\mathrm{d}$ to $\mathrm{He}$ & e $(\mathrm{H})$ & & & xpected & to Band & vagon ( & \\
\hline Exports & LOW & MED & $\mathrm{HIGH}$ & & LOW & $\mathrm{HIGH}$ & LOW & $\mathrm{HIGH}$ & $\mathrm{HIGH}$ \\
\hline Imports & LOW & HIGH & $\mathrm{HIGH}$ & & $\mathrm{HIGH}$ & $\mathrm{HIGH}$ & LOW & $\mathrm{HIGH}$ & $\mathrm{HIGH}$ \\
\hline SADC-FTA & NO & YES & YES & & YES & YES & YES & YES & YES \\
\hline Military & $\mathrm{HIGH}$ & LOW & HIGH & & $\mathrm{HIGH}$ & HIGH & LOW & HIGH & LOW \\
\hline Behaviour & $\mathrm{H}$ & B & $?$ & & $?$ & $?$ & $?$ & $?$ & B \\
\hline
\end{tabular}

Notes: Exports and imports are classified as high if they constitute more than 20 per cent of the country's total exports and imports, medium if between 10 per cent and 20 per cent, and low if less than 10 per cent. A threshold of two per cent of GDP separates high military expenditures from low military expenditures. All figures express the mean for the years 2000 to 2010 . The countries highlighted in grey conform to the expected behaviour. Sources: SIPRI Military Expenditures Database (2014); WTO Trade Profiles (2014).

greater regional power. All other states seem to have followed mixed strategies or strategies that bluntly contradict theoretical expectations - notice how Argentina, Mozambique, Venezuela and Zimbabwe have bandwagoned their respective regional unipole. Table 1 begs the question: Is the theory wrong? Or is there an intervening variable that explains the divergent strategies of similarly empowered countries? Most literature so far has opted for the first of these hypotheses, thus abandoning the structural framework, but I will argue otherwise.

Angola, Chile and Colombia present a stunning similarity when compared with other secondary regional powers such as Argentina, Mozambique, Venezuela and Zimbabwe, i.e. higher political stability. In the case of Chile and Colombia, this was achieved through democracy. In the case of Angola, strong authoritarian rule did the trick. The result in terms of foreign policy is, nevertheless, similar. The more stable the domestic politics, the more consistent the response to the unipolar context. Many authors before me have noticed that in developing countries domestic politics often intervenes to prevent balancing behaviour, ${ }^{32}$ and the logic often goes as follows: When internal politics are unstable and mandates are at stake, leaders perceive the national arena to be as harsh and anarchic as that of international politics and prioritize domestic threats.

Domestic political instability can materialize in different ways. Be it in the event of low party system institutionalization and recurrent presidential crises - as in the case of many South American countries - or the resurgence of violent protests or rebellion under authoritarianism - as in the case of many Southern African countries - heads of state are not expected to pay much attention to the power transitions taking place in their region. Foreign policy is more likely to become a tool for accumulating domestic power. Under these circumstances, countries that would have otherwise been rivals, can become allies and vice versa. 
Table 2. Indicators of political stability in South American countries.

\begin{tabular}{|c|c|c|c|c|c|c|c|c|c|}
\hline Countries & ARG & $\mathrm{CHI}$ & COL & VEN & PER & $\mathrm{BOL}$ & $\mathrm{ECU}$ & PAR & URU \\
\hline Expectations & \multicolumn{4}{|c|}{ Expected to Hedge $(\mathrm{H})$} & \multicolumn{5}{|c|}{ Expected to Bandwagon (B) } \\
\hline Government instability & $\mathrm{HIGH}$ & LOW & LOW & MED & MED & $\mathrm{HIGH}$ & $\mathrm{HIGH}$ & MED & LOW \\
\hline Electoral volatility & $\mathrm{HIGH}$ & LOW & LOW & HIGH & $\mathrm{HIGH}$ & MED & $\mathrm{HIGH}$ & LOW & LOW \\
\hline Delegative president & $\mathrm{HIGH}$ & LOW & LOW & HIGH & MED & LOW & MED & MED & LOW \\
\hline Behaviour & $\mathrm{B}$ & $\mathrm{H}$ & $\mathrm{H}$ & B & $?$ & $?$ & $\mathrm{H}$ & $?$ & B \\
\hline
\end{tabular}

Notes: Government instability is classified as low if there has been no presidential crisis, medium if there have been one or two, and high if three presidents were ousted between 1985 and 2013. The average electoral volatility for the period 1990-2011 is measured by the Pedersen index and classified as low if it is less than 35 per cent, medium if it is between 35 per cent and 48 per cent, and high if it is above 48 per cent. Finally, the delegative democracies index classifies countries according to an eight-point scale, which is divided here into low, $0-3$; medium, 3-5; and high, 5-8. The countries in grey conform to the expected behaviour.

Sources: Georgetown Political Data of the Americas database (2013) and the delegative democracies index developed by Lucas González.

When countries in South America are analysed according to party-system institutionalization, power concentration in the president, and presidential stability, three cases stand out as being more stable since democratization: Chile, Colombia and Uruguay. ${ }^{33}$ As predicted, these countries have behaved according to the unipolar structure. Chile and Colombia have consistently counterbalanced Brazil by strengthening economic ties with Washington and maintaining large military budgets. The small state of Uruguay has, despite its harsh tactical discourse, opted to tie itself structurally to Brazil. Conversely, the two secondary regional powers that have clearly underbalanced-Argentina and Venezuela - as well as Ecuador, the small state that has been more reluctant to bandwagon, are precisely those that have experienced more presidential crises, greater electoral volatility and stronger executives. Table 2 shows these results by analysing the long-term trajectories of South American democracies since regime transition.

In Southern Africa, internal stability was achieved through tight authoritarian control. In the Angolan case, the death of the rebel leader Jonas Savimbi in 2002 ended the civil war and stabilized the country. Since then, Angola has experienced unprecedented growth, driven by the boom in commodity prices. GDP growth rates have averaged 10 per cent since the year 2000. In 2008 alone, the country grew at an impressive 23.2 per cent. As shown earlier, this miraculous ascension had an impact on military expenditures and other indicators of international power.

Mozambique and Zimbabwe, on the other hand, are cases of protracted instability where competitive authoritarian regimes have been unable to consolidate. The Mozambican National Resistance (RENAMO) leader Afonso Dhklakama, who had been denouncing fraud continuously since the 1999 elections, announced the end of the Mozambican Peace Agreement and the country went back to civil war in April 2013. The case of Zimbabwe after the 2000 constitutional referendum has been more notorious; state repression and widespread violence earned Harare severe sanctions and the country reached second position in the list of failed states with an inflation rate of 13,000 per cent at the end of the decade, with a quarter of its population displaced. The Mugabe regime has been in economic dire straits from then on. In the 10 years from 1998 to 2008, Zimbabwe's cumulative GDP declined by 38 per cent.

Table 3 shows how stable authoritarian regimes that managed to suppress sources of domestic instability have responded to subsystemic incentives in the way predicted 
Table 3. Indicators of political stability in Southern African countries.

\begin{tabular}{|c|c|c|c|c|c|c|c|c|}
\hline Countries & ANG & MOZ & $\mathrm{ZLM}$ & BOT & LES & MAD & NAM & SWA \\
\hline Expectations & \multicolumn{3}{|c|}{ Expected to Hedge $(\mathrm{H})$} & \multicolumn{5}{|c|}{ Expected to Bandwagon (B) } \\
\hline Freedom of association & LOW & MED & MED & HIGH & MED & $\mathrm{HIGH}$ & HIGH & LOW \\
\hline Electoral competition & LOW & $\mathrm{HIGH}$ & $\mathrm{HIGH}$ & $\mathrm{HIGH}$ & HIGH & $\mathrm{HIGH}$ & $\mathrm{HIGH}$ & LOW \\
\hline Executive accountability & LOW & MED & MED & HIGH & MED & MED & $\mathrm{HIGH}$ & LOW \\
\hline Behaviour & $\mathrm{H}$ & $\mathrm{B}$ & $?$ & $?$ & $?$ & $?$ & $?$ & B \\
\hline
\end{tabular}

Notes: I use the V-Dem indicators to calculate means from 1990 to 2010. Freedom of association is classified as low if it is less than .5 and high if more than .75 , otherwise it is considered medium. To code electoral competition I use the Electoral Component Index and set a threshold at a .3 level to separate low from high electoral competition. Finally, I consider executive accountability to be low when executive oversight is less than 1 , medium if from 1 to 2 and then high. The countries in grey conform to the expected behaviour. Source: Varieties of Democracy Project ${ }^{34}$.

by structural considerations. Angola and Swaziland, the two countries that consistently undertook hedging and bandwagoning, respectively, are precisely the two that have more consolidated authoritarian regimes in Southern Africa. Measured by the V-Dem indicators, ${ }^{35}$ freedom of association, electoral competition and accountability of the executive, these two countries are at the regional lowest, but they have led to an outstandingly stable authoritarian peace.

In sum, Tables 2 and 3 show how secondary and tertiary state behaviours in these two unipolar regions are consistent with theoretical expectations when I include some measure of internal political stability. The South American and the Southern African contexts differ considerably. While the South American stability of Chile, Colombia and Uruguay is democratic and based on the stable interaction of more than one party, stability in Angola and Swaziland means autocratic control. However, the conclusions are similar. In countries where incumbent political elites and sitting heads of state encountered a more benign domestic environment, attention to subsystemic power dynamics was possible and a consistent foreign policy towards their regional unipoles was enacted.

Previous scholarship and conventional wisdom tend to see political alignments in South America and Southern Africa as driven by ideology. Parties that have grown out of the Latin American left or African anti-apartheid movements, so the story goes, share ideological goals, which determine their cooperation while in power. However, the evidence here shows that capabilities distribution and internal stability are far more consistent long-term explanations for the foreign policies of these countries. Ideological affinities between the Angolan Popular Movement for the Liberation of Angola (MPLA) and the South African African National Congress (ANC), as those between the Chilean Socialist Party and the Brazilian Workers Party, were real and had a certain effect in foreign policy, but could not prevent the enactment of hedging strategies in Luanda and Santiago.

A good rule of thumb is that ideology matters less as domestic political stability increases. The current relations between Brasilia and Caracas are an interesting case in point. The recent debate about the suspension of Venezuela from MERCOSUR is universally seen as a consequence of the rightist turn in the region. This is probably a fair-although simplistic and rather uninteresting - short-term assessment. A theory of regional unipolarity introduces some fundamental nuances. First, it would see an 
abrupt decision to suspend Venezuela, in part, as a consequence of domestic instability in Brazil-implying the counterfactual that without Rousseff's impeachment the turn would have been smoother. Second, it expects Brazil to act with special caution, coordinating always with Argentina and not getting unilaterally involved in Venezuelan domestic politics as it did during episodes of regime change in smaller states. Third, it expects that, as domestic politics become stable again in Brazil, a more consistent policy towards Venezuela will be formulated that will survive future ideological shifts in the Planalto.

\section{Conclusion}

The concept of unipolarity has seldom been applied to understand the dynamics of regional subsystems. Yet, understanding Brazil and South Africa as regional unipoles helps to explain not only their respective foreign policies but also those of their South American and Southern African neighbours.

In the account developed in this article, these unipolar regions work as follows: (a) Brazil and South Africa, the unipoles, lead by actively participating in binding regional institutions and building ad hoc regional 'coalitions of the willing' to deal with major security or economic challenges, struggle for legitimacy, do not apply a great deal of coercion and respect the sovereignty of second-tier states, which are often considered crucial partners. Then (b) secondary regional powers-Argentina, Chile, Colombia and Venezuela in South America; and Angola, Mozambique and Zimbabwe in Southern Africa - contest the Brazilian and South African primacy by maintaining low trade interdependence and by ensuring military readiness unless internal instability prevents this outcome. Finally, (c) small states-Bolivia, Ecuador, Paraguay and Uruguay, as well as Botswana, Lesotho, Madagascar, Malawi, Namibia and Swaziland-bandwagon the unipoles in their respective regions, again unless domestic politics trumps international incentives.

This article has illustrated this logic by means of aggregated data and broad intraand inter-regional comparisons. However, much more analytical detail is to be gained by analysing within-case variation, using process tracing or similar analytical tools. This logic should also explain other regions as long as they behave as a subsystem, are relatively isolated from great power politics and present unipolar distributions of material capabilities. The tense relation between Fiji and Australia is a case in point. After the 2006 military coup - a symptom of grave political instability - Fiji, otherwise expected to bandwagon, has had adversarial relations with its larger neighbour that are otherwise difficult to explain. Future work could apply this framework to Oceania, East Asia, South Asia, Eastern Europe or other regions of the world that have a regional unipole.

\section{Disclosure statement}

No potential conflict of interest was reported by the author.

\section{Notes}

1. Amitava Acharya, 'The Emerging Regional Architecture of World Politics', World Politics, 59 (4), 2007, pp. 629 652; Barry Buzan and Ole Waever, Regions and Powers: The Structure of International Security, Cambridge University Press, Cambridge, 2003; Peter Katzenstein, A 
World of Regions: Asia and Europe in the American Imperium, Cornell University Press, Ithaca, NY, 2005.

2. By structural theory or structural framework I mean IR theories that predict conflict or cooperation based fundamentally on considerations about the relative power capabilities of states. In principle, this is the case for balance of power theory, hegemonic stability theory and power transition theory, among others. See Robert Gilpin, War and Change in International Politics, Cambridge University Press, Cambridge, 1981; Kenneth Waltz, Theory of International Politics, McGraw Hill, New York, NY, 1979; Abramo Organski, Jacek Kugler, The War Ledger, University of Chicago, Chicago, IL, 1980.

3. For some notable exceptions see David Lake, Patrick Morgan, Regional Orders: Building Security in a New World, Pennsylvania State University Press, University Park, 1997; Douglas Lemke, Regions of War and Peace, Cambridge University Press, Cambridge, 2002; Randall Schweller, Unanswered Threats: Political Constraints on the Balance of Power, Princeton University Press, Princeton, NJ, 2006.

4. See Kenneth Waltz, no. 2, p. 73; Douglas Lemke, no. 3.

5. Cameron G. Thies, Marijke Breuning, 'Integrating Foreign Policy Analysis and International Relations through Role Theory', Foreign Policy Analysis, 8(1), 2012, pp. 14.

6. Daniel Flemes, Steven Lobell, 'Contested Leadership in International Relations', International Politics, 52(2), pp. 139145

7. T.V. Paul, Deborah Larson, William Wohlforth, Status in World Politics, Cambridge University Press, Cambridge, 2014.

8. Janis van der Westhuizen, 'Brazil and South Africa, the Odd Couple of the South Atlantic?', Commonwealth and Comparative Politics, 54(2), 2016, pp. 232251.

9. G. John Ikenberry, Michael Mastanduno, William Wohlforth, 'Unipolarity, State Behavior, and Systemic Consequences', World Politics, 61(1), 2009, pp. 1 27, here p. 5; Stephen Brooks, William Wohlforth, World out of Balance: International Relations and the Challenge of American Primacy, Princeton University Press, Princeton, NJ, 2008; David Wilkinson, 'Unipolarity without Hegemony', International Studies Review, 1(2), 1999, pp. 141172.

10. Sean Burges, 'Consensual Hegemony: Theorizing the Practice of Brazilian Foreign Policy', International Relations, 22(1), 2008, pp. 65 84; Andrés Malamud, 'A Leader without Followers? The Growing Divergence between the Regional and Global Performance of Brazilian Foreign Policy', Latin American Politics and Society, 53(3), 2011, pp. 124.

11. Fred Ahwiring, Patrick McGowan, 'Partner of Hegemon: South Africa in Africa', Journal of Contemporary African Studies, 16(1), 1998, pp. 165 195; James Hamill, 'From Realism to Complex Interdependence?', International Relations, 14(3), 1998, pp. 1 30; Adam Habib, Nthakeng Selinyane, 'Constraining the Unconstrained: Civil Society and South Africa's Hegemonic Obligations in Africa', in Walter Carlnaes, Philip Nel (eds.), In Full Flight: South African Foreign Policy after Apartheid, Institute for Global Dialogue, Mirand, 2006, pp. 175 194; Maxi Schoeman, 'South Africa as an Emerging Middle Power: 1994 2003', in John Daniel, Adam Habib, Roger Southall (eds.), State of the Nation: South Africa 2003 2004, HSRC, Cape Town, 2004, pp. 349367.

12. Martha Finnemore, 'Legitimacy, Hypocrisy, and the Social Structure of Unipolarity: Why Being a Unipole Isn't All It's Cracked up to Be', World Politics, 61(1), 2009, pp. 58 85; William Wohlforth, 'The Stability of a Unipolar World', International Security, 21(2), 1999, pp. 5 41; Stephen Walt, 'Alliances in a Unipolar World', World Politics, 61(1), 2009, pp. 86120 .

13. My proposition is that countries behave in the way prescribed by capability distribution only when they are stable at the domestic level. Proponents of 'omnibalancing' have been the first to put this argument forward: see Steven David, 'Explaining Third World Alignment', World Politics, 43(2), 1991, pp. 233 256. The point will be discussed further in the section 'Secondary regional powers under unipolarity', but my argument is basically the following. In unipolar regional contexts, second-tier regional powers enact contestational strategies when their domestic politics are stable. Contrariwise, in contexts of internal instability, secondary regional powers prioritize their domestic problems and bandwagon the regional unipole.

14. See David Wilkinson, no. 9. A literature review suggests that six fundamental dimensions characterize hegemony: it is a situation of (1) great material asymmetry in favour of one state the hegemon who has (2) enough military power to systematically defeat any potential contester in the system, (3) controls the access to rough materials, natural resources, capital 
and markets, (4) has competitive advantages in the production of value-added goods, (5) generates an accepted ideology reflecting this status quo, and (6) is functionally differentiated from other states in the system, being expected to provide certain public goods such as security or commercial and financial stability. This definition is consistent amongst renowned authors from different subfields and backgrounds that directly theorized about hegemonic relations and is also used by most IR scholars that employ the concept. See Robert Gilpin, no. 2; Robert Keohane, After Hegemony, Princeton University Press, Princeton, NJ, 1984; Charles Kindleberger, The World in Depression, 1929-1939, University of California Press, Berkeley, CA, 1973;Stephen Krasner, 'State Power and the Structure of International Trade', World Politics, 28(3), 1976, pp. 317347.

15. Randall Schweller, no. 3; Félix Martin, Militarist Peace in South America: Conditions for War and Peace, Palgrave, New York, 2006; Luis Schenoni, The Brazilian Rise and the Elusive South American Balance, GIGA Working Paper Series, 267, 2015, pp. 123.

16. Singer, David, Stuart Bremer and John Stuckey, 'Capability Distribution, Uncertainty, and Major Power War, 1820-1965', in Russett, Bruce (ed.), Peace, War; and Numbers, Sage, Beverly Hills, 1972, pp. 1948.

17. SIPRI, 'Mlitary Expenditures Database', Stockholm International Peace Research Institute, 2015, at http://www.sipri.org/databases

18. William Martin, 'South Africa and the "New Scramble for Africa", Agrarian South Joumal of Political Economy, 2(2), 2013, pp. 161188.

19. G. John Ikenberry, Michael Mastanduno, William Wohlforth, no. 9; Stephen Brooks, William Wohlforth, no. 9; David Wilkinson, no. 9.

20. William Martin, no. 16, p. 167.

21. Detlef Nolte and Leslie Wehner, 'UNASUR and Regional Security in South America', in Stephen Aris and Andreas Wenger (eds.), Regional Organisations and Security: Conceptions and Practices, Routledge, London, 2012, pp. 183202.

22. The frustrated negotiations between MERCOSUR and the European Union on trade liberalization are a clear example of how Brazil can be impeded from following its own interest by countries with more protectionist stances. Even after Mauricio Macri was elected in Argentina therefore aligning with Brazil in this issue a single country like Venezuela could paralyse the bloc by inhibiting consensus.

23. Daniel Flemes, 'Regional Power South Africa: Co-operative Hegemony Constrained by Historical Legacy', Joumal of Contemporary African Studies, 27(2), 2009, pp. 135157 , here p. 153.

24. Laurie Nathan, Community of Insecurity, Ashgate, London, 2012.

25. Even the $2000 \mathrm{SADC}$ free trade protocol which was arguably a South African initiative considered balancing measures, such as budgetary transfers, a regional development fund and postponed trade liberalization prioritizing the weakest members.

26. G. John Ikenberry, Michael Mastanduno, William Wohlforth, no. 9.

27. Aníbal Pérez-Liñán, Presidential Impeachment and the New Political Instability in Latin America, Cambridge University Press, Cambridge, 2007.

28. Andrés Malamud, Júlio Rodriguez, 'Straddling the Region and the World: Brazil's Dual Foreign Policy Comes of Age', in Marc Herzog, Philip Robins (eds.), The Role, Position and Agency of Cusp States in International Relations, Routledge, London, 2014, pp. 111 128; Daniel Flemes, no. 21 .

29. Félix Martin, no. 15.

30. Samuel Huntington, 'The Lonely Superpower', Foreign Affairs, 78(2), 1999, pp. 35 49, here p. 42 ; William Wohlforth, no. 12 , p. 31 .

31. Conceptually, the difference between secondary regional powers and small states is that the former have enough resources to affect the subsystem by forming alliances with a relatively small number of their peers. Small states, in contrast, have so little power that they would have to coordinate huge alliances to generate an effect. See David Mares, 'Middle Powers under Regional Hegemony: To Challenge or Acquiesce in Hegemonic Enforcement', International Studies Quarterly, 32(4), 1988, pp. 453 471. A small state is defined here by using a capability threshold as a state that has less than one third of the CINC of the first-ranked secondary state in the system depending on the moment in time, these are Zimbabwe or Angola, and Argentina or Colombia.

32. Randall Schweller, no. 3; Steven David, no. 13. 
33. Aníbal Pérez-Liñán, no. 25; Matthew Shugart, John Carey, Presidents and Assemblies: Constitutional Design and Electoral Dynamics, Cambridge University Press, Cambridge, 1992; Lucas González, 'Unpacking Delegative Democracy: Digging into the Empirical Content of a Rich Theoretical Concept', in Daniel Brinks, Marcelo Leiras, Scott Mainwaring (eds.), Reflections on Uneven Democracies: The Legacy of Guillermo O'Donnell, Johns Hopkins University Press, Baltimore, MD, 2013; Mariana Llanos, Leiv Marsteintredet, Presidential Breakdowns in Latin America. Causes and Outcomes of Executive Instability in Developing Democracies, Palgrave Macmillan, New York, 2010; Scott Mainwaring, Timothy Scully, Building Democratic Institutions: Party Systems in Latin America, Stanford University Press, Stanford, CA, 1995.

34. Michael Coppedge, John Gerring, David Altman, Michael Bernhard, Steven Fish, Allen Hicken, Matthew Kroenig, Staffan I. Lindberg, Kelly McMann, Pamela Paxton, Holli A. Semetko, Svend-Erik Skaaning, Jeffrey Staton, and Jan Teorell, 'Conceptualizing and Measuring Democracy: A New Approach,' Perspectives on Politics, 9(2), 2011, pp. 247267.

35. Michael Coppedge, John Gerring, with David Altman, Michael Bernhard, Steven Fish, Allen Hicken, Matthew Kroenig, Staffan I. Lindberg, Kelly McMann, Pamela Paxton, Holli A. Semetko, Svend-Erik Skaaning, Jeffrey Staton, Jan Teorell, 'Conceptualizing and Measuring Democracy: A New Approach', Perspectives on Politics, 9(2), 2011, pp. 247267. 